\title{
Practice and Exploration of the Dual-track Project Teaching Method in University Teaching
}

\author{
WANG Hua-ji \\ Henan University of Traditional Chinese Medicine, Student work Department ,Henan
}

\begin{abstract}
The dual-track project teaching method can improve the students' practical ability, innovation skills, collaboration skills and the construction of knowledge system. In the dual-track project teaching method, the role of the dominant position of students is fully developed, the enthusiasm of students is mobilized, the abilities of students' independent thinking, practices and collaboration are improved, and also the leading role of teachers is played. The effectiveness of teaching and learning is improved during the process of teachers' capitalizing on the trend and summering reflection. This paper makes a theoretical research and practical exploration of the dual-track project teaching method in higher education by use of interviewing method and practical teaching method, and proposes to define the meaning of the dual-track project teaching method and assign the role of teachers, students and environment settings, using constructivism and systems theory as a theoretical basis. With systematic, scientific and developmental as course design principles, the paper introduces the process of teaching and learning of the dual-track project teaching method. Using the application of the dual-track project teaching method in college computer basic curriculum Visual FoxPro program design as an example, the paper proposes that the dual-track project teaching method still need improving.
\end{abstract}

Keywords-dual-track project teaching method; teaching methods; Higher Education

\section{INTRODUCTION}

With the development of modern teaching theory and educational technology, there have been unprecedented prosperous in the study of teaching methods. Traditional teaching stresses on the transmission of knowledge, accustomed to increasing students' knowledge by way of injection and teacher's whole class teaching. Traditional teaching methods stresses the main role of the teacher, ignoring the main role of students, and students are at a passive position in the entire learning process. In order to change the passive position of students in traditional teaching methods, there have appeared some effective teaching methods for different students, different curricula and different teaching environment. These teaching methods stress dominant position of students more or less, and strengthen the students' ability cultivation.

From the late 1950s to the early 1960s, American psychologist Bruner proposed teaching "learner-centered" theory. In 1978, psychologist Ausubel proposed cognitive structure assimilation theory, which is cognitive learning theory. In 1963 Carour proposed cognitive symbolic learning theory, pointed out that the advantage of this theory is to develop a comprehensive and practical ability compared to the stimulus - response learning theory (SR). These theories laid the foundation for the formation of constructivism teaching theory.

Since the 1980s, constructivism learning theory which based on cognitive learning theory is gaining popularity in the field of science teaching, and becomes the mainstream of international science education reform theory. The point of constructivism was brought by the Swiss psychologist Jean Piaget in 1966. The direct pioneers of modern constructivism are Piaget and Vygotsky's theory of intellectual development. In 1970 Piaget published The Principles of Genetic Epistemology, mainly studies the formation and development of knowledge. Constructivism teaching method is the further development of cognition. Constructivists think that they construct the reality based on their own experience. Because of different experience of each person and different faith to the experience, the understanding of the outside world is different. Based on constructivism learning theory, a series of teaching methods have appeared, such as random access to teaching, situational teaching and scaffolding instruction. With our in-depth exploration of constructivism theory, we have made great achievements in the study of pedagogy, forming four teaching experiments families which have great impact: Learning and leading teaching, objectives teaching, situational teaching and creative teaching. In recent years, the task-driven teaching method, case teaching method and the project teaching method are also widely used in higher education teaching and learning activities.

\section{COMMON TEACHING METHODS OF HIGHER} EDUCATION AND THE ADVANTAGES AND DISADVANTAGES

\section{A. Task-driven teaching method}

Task-driven teaching method is a teaching method based on constructivism learning theory, teachers teaching and students learning are around a specific goal, based on several tasks, driven by a strong thirst for knowledge, through active application of learning resources, make a selfexploration and interactive collaborative learning, and perform a given task at the same time have a new task. Taskdriven teaching method emphasizes students should study in a real-life situation, in the task of driving, in the process of exploration to complete the task or solve the problem, in autonomous and collaborative environment and in the atmosphere of the discussions and conversations. Students can not only acquire knowledge, but also develop practical ability, which improves the students' spirit of exploration and 
innovation. During the process of completing the task, students are always in a dominant position. Teachers are the creators of learning situations, the designers of the learning task, the providers of learning resources, the organizers of the learning activities and the guiders of learning methods.

The most significant features of the task-driven teaching method is students are in the main position, which fully reflects the student-centered teaching ideas, changes the passive situation of students' passive acceptance in traditional teaching methods. Task-driven teaching method is easy to stimulate and maintain students' learning initiative and enthusiasm, to exercise students' cooperation spirit and communication skills, to develop students' practical and innovative ability, to promote the development of students' personality, to enhance the students' spirit of exploration and exercise students' indomitable will. But the nonlinear organization method of teaching content of task-driven pedagogy is more difficult to take the systematic knowledge into account, and is difficult for students to form a complete knowledge structure, which weakens the theoretical study. The knowledge related to the tasks in task-driven pedagogy is still partial relative to the entire course.

\section{B. Project teaching method}

Project teaching method is a teaching and learning activity through the implementation of a complete project. In teaching activities, teachers give students problems to be resolved or tasks to be completed in the form of a project, under the guidance of teachers, students complete the entire project either by means of individual or group work, during which students make the plan in accordance with the actual work complete program. In project teaching method, the learning process has become a place where everybody are involved in the creation of practical activities, and in the process of project practice, students understand and grasp knowledge and skills required in the course, experience the hardships and fun of innovation, develop the ability of analyzing and solving problems, teamwork skill and cooperating ability. Project teaching method is a set of teaching strategies, when teachers successfully implement the project teaching, the enthusiasm of the students will be greatly inspired, and they will consciously study and complete the project homework with high quality.

When using the project teaching method to design teaching, students are the main body of the cognitive, the active constructor of knowledge meaning. In the project pedagogy teaching practice, teachers played the autonomy of the students in a large extent in the teaching process, stressed that the main role of students throughout the learning process. In the arrangement of teaching content, emphasized the connectivity of knowledge and development of technology and skills.

Seeing from teaching practices, project pedagogy indeed greatly improve the ability of students' learning and using knowledge freely, and practical ability has been significantly improved. However, the integrity and systematic of the theoretical knowledge are weakened in the teaching practice. Existing teaching practice emphasized the focus of the training program is basically a knowledge module or unit of knowledge, not the overall significance of the whole curriculum, in particular, the emergence and flourishing of interdisciplinary makes each course or subject cannot exist separately. In a course teaching how to realize its own characteristics, value, and apply the knowledge of other courses at the same time, so that they can complement each other. This is an educational practice questions to be explored.

\section{DUAL-TRACK PROJECT TEACHING METHOD BASED ON CONSTRUCTIVISM AND SYSTEMS THEORY}

\section{A. Theoretical basis}

Dual-track project teaching method is emphasizing both learning process and teaching process, and both construction of the knowledge system and the formation of practical work experience. In dual-track teaching, emphasizes not only students build the knowledge structure and makes skill training in real situation through collaborative learning, but emphasizes teachers' succinctly and critical knowledge of the various modules, as well as knowledge point summary at the end of each module stage, knowledge architecture structures, experience summary and experience structure build. The principle of the dual-track project teaching method is shown in Figure 1.

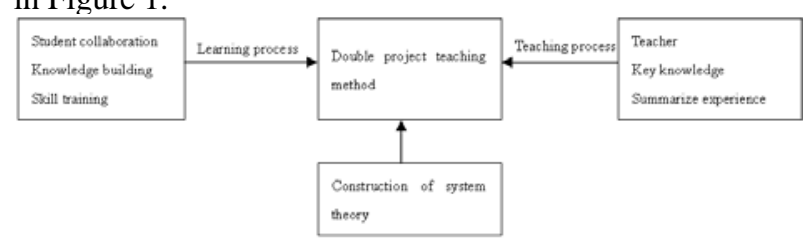

Figure 1. Dual-track project teaching method block diagram

\section{B. The meaning of the dual-track project teaching method}

Dual-track project teaching method melts the knowledge and technology of a course together with its realworld applications, designed as a course project. Students are guided by teachers to solve practical problems by use of the knowledge and skills step-by-step, and to complete the project. The scale of the problem complexity is from small to large, from simple to difficult. The leading role of teachers in the teaching process is to sum up focus emphasis succinctly, summarize knowledge and experience, help students build a complete course of knowledge, experience system; students are the subject of learning, and to give full play to the role of collaborative learning, so that students acquire the knowledge forming ability in collaboration and guidance.

The dual-track project teaching method is a new teaching method which is a collection of the advantages of task-driven teaching method and the traditional teaching method. It is more applicable to the teaching of higher education. Higher education requires students to form a complete knowledge of architecture in addition to the 
formation of certain practical skills and a sense of responsibility and professional capacity for sustainable development. So that if the university theory courses are seen as a sub-chapter, the words of the knowledge points of the sub-section is not conducive to the formation of the various capabilities of students. The isolated knowledge points resulted in the isolation of the students' knowledge, so that they cannot apply knowledge to work and study. The dualtrack project teaching method can solve the problem of combining theory and practice.

\section{THE PRACTICE OF DUAL-TRACK PROJECT TEACHING METHOD IN UNIVERSITY TEACHING}

\section{A. Dual-track project teaching steps}

In dual-track project teaching method, teaching content should be one or several course projects close to the real project. The operation period of course project can be set accordingly. Using universities Visual FoxPro program design as an example, the research explores the application of the dual-track project teaching method in teaching practice. The case asks students to design a students' achievements management system as a course project. In order to improve students' learning enthusiasm and interest, it is allowed for students to take advantage of the VFP to design a simple student naturally database first, the contents of the tables in the database can only browse through the menu. So that students learn to apply the knowledge during the process of understanding the basic knowledge of the VFP. Students complete the course learning through the means of material collection, hands-on practice and communication between the students. Teachers summarize the point of knowledge and operation experience after the completion of the course project. Students' intrinsic motivation can be effectively stimulated and the motivation and potential of the knowledge and skills for self-development are formed, teachers only need to prepare the corresponding guidance. In the completion of the simple course project content and then increase the difficulty and requirements, by increasing the content and functionality, realize the addition of difficulty of learning and knowledge content, until the last completed a perfect student management system. Give an evaluation according to the evaluation method after the completion of the project. In the implementation process of the course project, students can not only master the knowledge and skills of VFP, but also form the ability to apply this knowledge and skills to solve problems in practical work.

\section{B. General steps of dual-track project teaching}

Dual-track project teaching usually takes the following steps to teach:

The first step: the demonstrating phase of the project. Teachers first demonstrate project examples to explain the functions and knowledge of the instance, arouse the curiosity of students, and then students are divided into groups according to the needs of curricula and the number of students.

The second step: the preparatory phase of the curriculum implementation. Teachers give students the general requirements of course project, and guide students to analyze curriculum project, divide a complete course project into multiple courses projects from simple to complex. Teachers provide students with basic teaching facilities, learning materials and necessary experimental conditions, each group students analyze the curriculum requirements of the project, collect information related to course project, give design plan after group discussion.

The third step: teachers and students discuss the feasibility of the curriculum project, the necessary knowledge and technology, and perfect the curriculum project design program. Teachers should ensure that at least three final feasible courses are different.

The fourth step: teachers explain the knowledge and technology involved in the project during the process of project design and implement.

The fifth step: the implementation phase of project. According to the progress of the design of the course project, students completed the self-learning and project implementation.

The sixth step: the demonstration of group design results, identify advantages and disadvantages. Select the most effective part of the learning from each group and have mutual communicative learning.

The seventh step, teachers conclude the knowledge and experience of this stage after the end of exchanging to form a complete knowledge system and experience system. Each group further improves the design program.

The eighth step, repeat step five to step seven, until the completion of all the contents of the project.

The ninth step, each group presents their work, evaluate students' learning according to the scheduled evaluation methods.

\section{Teachers' role, students' role and environment settings}

TABLE I. TEACHERS’ ROLE AND STUDENTS' ROLE

\begin{tabular}{|l|l|l|}
\hline \multicolumn{1}{|c|}{ Steps } & \multicolumn{1}{|c|}{ Teachers' role } & \multicolumn{1}{c|}{ students' role } \\
\hline $\begin{array}{l}\text { demonstrate } \\
\text { course project }\end{array}$ & $\begin{array}{l}\text { Demonstration of typical } \\
\text { examples, explain } \\
\text { function and the point of } \\
\text { knowledge. Motivate the } \\
\text { activeness of students }\end{array}$ & $\begin{array}{l}\text { observe sample project, } \\
\text { thinking, analyzing the } \\
\text { problem to be solved, } \\
\text { give your understanding }\end{array}$ \\
\hline $\begin{array}{l}\text { Course project } \\
\text { preparation }\end{array}$ & $\begin{array}{l}\text { Provide the necessary } \\
\text { learning resources: } \\
\text { materials, courseware, } \\
\text { books and other } \\
\text { reference materials }\end{array}$ & $\begin{array}{l}\text { Students make demand } \\
\text { analysis for the product, } \\
\text { make a preliminary } \\
\text { design descriptions }\end{array}$ \\
\hline $\begin{array}{l}\text { Feasibility } \\
\text { study }\end{array}$ & $\begin{array}{l}\text { Analysis: requirement } \\
\text { specification, knowledge } \\
\text { gathering, design } \\
\text { description. determine } \\
\text { the project of each group } \\
\text { after discussion }\end{array}$ & $\begin{array}{l}\text { To participate in the } \\
\text { discussion and found } \\
\text { deficiencies and } \\
\text { problems of work and } \\
\text { improve in time }\end{array}$ \\
\hline Advance & $\begin{array}{l}\text { Succinctly teaching the } \\
\text { Learn the basics to lay }\end{array}$ \\
\hline
\end{tabular}




\begin{tabular}{|l|l|l|}
\hline $\begin{array}{l}\text { knowledge } \\
\text { teaching }\end{array}$ & basic section of course & $\begin{array}{l}\text { the foundation for future } \\
\text { learning }\end{array}$ \\
\hline $\begin{array}{l}\text { The } \\
\text { implementation } \\
\text { of the project }\end{array}$ & $\begin{array}{l}\text { Guide students to } \\
\text { implement curriculum } \\
\text { projects, monitor the } \\
\text { progress of the project. } \\
\text { Proper guidance and } \\
\text { help students to find a a } \\
\text { solution to the problem }\end{array}$ & $\begin{array}{l}\text { While learning the } \\
\text { basics, attempt to } \\
\text { implement a dual-track } \\
\text { project. Try to solve } \\
\text { problems by self when } \\
\text { encountering problems. }\end{array}$ \\
\hline $\begin{array}{l}\text { Stage show } \\
\text { Summary }\end{array}$ & $\begin{array}{l}\text { Analysis of learning and } \\
\text { project implementation, } \\
\text { identify problems, sum } \\
\text { up experience and } \\
\text { lessons To build the } \\
\text { knowledge structure. }\end{array}$ & $\begin{array}{l}\text { Exchange program } \\
\text { project implementation } \\
\text { experience and problems } \\
\text { with students and } \\
\text { teachers. Solve the } \\
\text { difficult encountered } \\
\text { problems. }\end{array}$ \\
\hline $\begin{array}{l}\text { Improvement } \\
\text { course project } \\
\text { design }\end{array}$ & $\begin{array}{l}\text { To help students solve } \\
\text { difficult problems }\end{array}$ & $\begin{array}{l}\text { Improve their courses } \\
\text { and help students of the } \\
\text { same group master the } \\
\text { knowledge and skills on } \\
\text { the basis of experience } \\
\text { summary. }\end{array}$ \\
\hline $\begin{array}{l}\text { Expand the } \\
\text { curriculum } \\
\text { project }\end{array}$ & $\begin{array}{l}\text { Knowledge is gradually } \\
\text { added to the curriculum } \\
\text { project, to enhance the } \\
\text { curriculum project } \\
\text { function }\end{array}$ & $\begin{array}{l}\text { To learn new knowledge } \\
\text { and improve the } \\
\text { curriculum project }\end{array}$ \\
$\begin{array}{l}\text { To evaluate the } \\
\text { formation of student } \\
\text { mastery of knowledge, } \\
\text { skills }\end{array}$ & $\begin{array}{l}\text { To evaluate learning } \\
\text { outcomes between } \\
\text { themselves and the same } \\
\text { group of students }\end{array}$ \\
\hline
\end{tabular}

D. Problems to be solved in the dual-track project teaching method

Although dual-track project teaching method can improve the students' practical ability, innovation ability and collaboration ability, the practice of dual-track project teaching method also encountered some problems such as the shortage of teaching resources, teaching materials construction and so on, the current basic teaching materials are edited based on subject knowledge system, when implement the project teaching method, teachers not only need to design course project in close connection with the teaching materials and select demonstration projects but also need to prepare the network courseware, the content and form of courseware should also apply to the use of the dualtrack project teaching activities.

\section{CONCLUSION}

Dual-track project teaching method stresses the dominant position of students and leading role of teachers, and mobilizes the enthusiasm of students; improve students' abilities of independent thinking, practicing and collaboration, while improving the effectiveness of teaching and learning. The practice of dual-track project teaching method still requires more teachers to fundamentally change teaching ideas, continuously improve the dual-track project teaching method in practice, and make this teaching method more rigorous in theory and more mature in practice.

\section{REFERENCES}

[1] William F. Pinar . International Handbook of Curriculum Research[M]. Lawrence Erlbaum.,in 2003.

[2] William F. Pinar. What is Curriculum Theory[M]. Lawrence Erlbaum,in 2004.

[3] Charles Fisher,David C. Dwyer, Keith Yocam . Education \& Technology:Reflections on Computing in Classrooms[M]. Apple Press, Jossey-Bass Publishers, San Francisco, in 1996. 